\title{
OPUSTOŠENA ZEMLJA: DVA ENGLESKA SVEDOČANSTVA O PRVOM SVETSKOM RATU U SRBIJI
}

Oslanjajući se na pojam balkanizma Marije Todorove, ovaj rad analizira dva engleska putopisa iz Prvog svetskog rata nedavno objavljena u Srbiji - Opustošena zemlja: Srbija kako smoje mi videli, bračnog para Alis i Kloda Askjua i Plameni maču Srbiji $i$ drugde autorke Mejbel Sinkler Stobart - da bi pokazao koliko su disonantni u odnosu na dominantni diskurs vremena u kojem su nastali. Umesto prezrivog i nipodaštavajućeg stava o ovom delu Evrope, autori putopisa, koji su u Srbiji boravili u periodu zatišja u borbama u proleće i leto 1915. godine, a potom se sa srpskom vojskom povlačili preko Srbije, Crne Gore i Albanije u jesen i početkom zime iste godine, prema Srbima izražavaju poštovanje i divljenje, a oštro kritikuju sramnu izdaju Saveznika.

Ključne reči: Prvi svetski rat, Srbija, balkanizam, ratni putopisi.

\section{UvoD}

Stogodišnjica prvog svetskog rata obeležava se u srpskoj kulturi brojnim sadržajima - knjigama, filmovima, televizijskim reportažama, pozorišnim predstavama i umetničkim postavkama. Taj raznovrsni materijal nudi obilje dragocenih i neretko nepoznatih svedočanstava patnji, stradanja i herojstva pripadnika srpskog naroda i srpske vojske u dotada najvećem ratnom sukobu u istoriji čovečanstva. Među nedavno objavljenim publikacijama relevantnim za studije engleske književnosti izdvajaju se dva ratna putopisa. Prvi je Opustošena zemlja: 
Srbija kako smo je mi videli, čiji su autori bračni par Alis i Klod Askju (Alice and Claude Askew, The Stricken Land: Serbia As We Saw It), a drugi - Plameni mač u Srbiji i drugde, autorke Mejbel Sinkler Stobart (Mrs. St. Clair Stobart, The Flaming Sword in Serbia and Elsewhere). Oba putopisa na srpski jezik preveo je Branko Momčilović, a objavljeni su u razmaku od četiri godine - Opustošena zemlja u izdanju novosadskog Platoneuma 2012, a Plameni mač u izdanju novosadskog Prometeja i Radio televizije Srbije, 2016. godine.

Neobične su i brojne podudarnosti između ova dva putopisa. Njihovi autori, bračni par Askju i Mejbel Sinkler Stobart, stigli su u Srbiju u aprilu 1915. godine, posle plovidbe iz Engleske do Soluna brodom Saidija, a potom vozom preko Skoplja. U Srbiji su boravili tokom zatišja u borbama u proleće i leto te godine, a potom su, početkom oktobra, zajedno sa srpskom vojskom i narodom krenuli u iscrpljujuće i tragično tromesečno povlačenje, od Pirota do Medove u Albaniji. Oba putopisa o ratnim iskušenjima Srba autori su objavili u Londonu naredne godine, 1916, sa idejom da svoje sunarodnike upoznaju sa hrabrošću i slobodarskim duhom malog balkanskog naroda o kome se u Engleskoj nije mnogo znalo, a ono što je bilo poznato, najčešće je po Srbe bilo nepovoljno. U Srbiji se razdoblje Prvog svetskog rata, osim po nepojmljivim strahotama, pamti i po prisustvu mnogobrojnih stranih, najviše britanskih humanitarnih misija i požrtvovanih pojedinaca, koji su u skladu sa svojim mogućnostima i obučenošću nastojali da ublaže ratne patnje Srba.

Pisana svedočanstva o boravku u Srbiji Alis i Kloda Askjua i Mejbel Sinkler Stobart značajna su još i po tome što predstavljaju radikalni otklon od onoga što Marija Todorova u svom uticajnom delu Imaginarni Balkan (Maria Todorova, Imagining the Balkans, 1999) naziva diskursom balkanizma. Diskurs balkanizma može se definisati kao negativni stereotip o Balkanu prisutan u zapadnoj kulturi i u značajnoj meri uslovljen politikom. U britanskoj kulturi prvi putopisi o Balkanu nastaju u osamnaestom, a njihov broj raste u narednom, devetnaestom veku, kada se formira i učvršćuje negativni stereotip o Balkanu. Načelan stav Engleza prema evropskom delu Osmanske carevine Todorova opisuje rečima: „prirodna empatija sa vladaocima 
i tradicionalna netrpeljivost prema muslimanima, ali je veoma često prvi sentiment umeo da prevlada" (Todorova 1999: 163). Takav stav postaje još aktuelniji posle 1830. godine, kada je Britanija, kao najvažnija svetska industrijska i trgovačka sila, zbog ravnoteže moći, počela da se zalaže za očuvanje integriteta i nepovredivosti Osmanskog carstva. Ovakvim kursom Britanije na spoljnom planu objašnjava se vidljiva politizacija putopisa nastalih u devetnaestom veku: njihovi autori jasno izlažu svoje političke stavove, koji su gotovo uvek saglasni sa zvaničnom političkom linijom (1999: 169). Kada je reč o pokorenom hrišćanskom življu na Balkanu, uz ogradu da svako uopštavanje podrazumeva izuzetke, Todorova navodi (1999: 173) da su „aristokrate uglavnom bile turkofili, dok je liberalna srednja klasa bila naklonjenija hrišćanskim narodima”. Važan izuzetak predstavljaju ugledne pripadnice više klase, Adelina Polina Irbi i Džordžina Mjur Mekenzi, koje su u svom delu Putovanja po slovenskim krajevima evropske Turske (Adeline Pauline Irby and Georgine Muir Mackenzie, Travels in the Slavonic Provinces of Turkey-in-Europe, 1866) britansku publiku upoznale sa dotada praktično nepoznatom temom, sa patnjom potčinjenih slovenskih naroda, i verovatno uticale na Vilijama Gledstona koji je revidirao svoje turkofilske stavove (Momčılović 1993: 166), kako bi u javnom delovanju počeo da ukazuje na to da se ne sme ignorisati stanje u kojem se nalaze potčinjeni narodi u Osmanskom carstvu (ToDoRova 1999: 175). Todorova, međutim, podseća (1999: 181) da, uprkos ugledu Irbijeve, Mekenzijeve, Gledstona i još nekih javnih delatnika, njihovi stavovi ipak nisu bili naročito uticajni, odnosno da je dominantni diskurs, čak i kada je kritikovao osmansku vlast kao samovoljnu, despotsku i necivilizovanu, izbegavao rasne pogrde muslimana ili Turaka, dok je Južne Slovene otvoreno smatrao nesposobnim da se uspešno i samostalno razvijaju.

Zahvaljujući ovakvom pogledu na stvari, početkom dvadesetog veka na Zapadu je već bila izgrađena nepovoljna slika o Balkanu, a potom je dalje učvršćivana kroz tragične događaje koji su usledili. Reputacija Srba dodatno je narušena ubistvom kralja Aleksandra Obrenovića i kraljice Drage, maja 1903. godine u Beogradu, a Srbija je otvoreno proglašavana krivom i za atentat na Franca Ferdinanda u 
Sarajevu, odnosno za izbijanje Prvog svetskog rata. Todorova navodi rezultate jednog istraživanja (1999: 209) iz kojeg se vidi da su u nemačkim i austrijskim ratnim izveštajima o Balkanu od 1912. do 1918. godine obilato korišćene uopštavajuće etikete kao što su „orijentalno” - „da označi prljavštinu, pasivnost, nepouzdanost, mizoginiju, sklonost ka spletkarenju, neiskrenost, oportunizam, lenjost, sujeverje, letargiju, tromost, neefikasnost, nesposobnu birokratiju” - i „balkansko” - u smislu „okrutnosti, neotesanosti, nestabilnosti i nepredvidivosti”. Ukoliko se imaju na umu ovi i mnogobrojni drugi primeri prezrivih stavova Zapada o ovom delu Evrope ${ }^{1}$, utoliko su značajniji i osobeniji ratni putopisi bračnog para Askju i Mejbel Sinkler Stobart, zapanjujuće disonantni u odnosu na dominantni diskurs vremena u kojem su nastali.

Budući da su njihovi autori u Srbiji boravili u isto vreme - od aprila do kraja decembra 1915. godine - u ratnim putopisima primetna je podudarnost u strukturnom smislu. U oba putopisa moguće je uočiti

1 Todorova (1999: 205-6) navodi negativne stavove nekoliko engleskih autora iz ovog perioda. Hari De Vint (Harry de Windt) svoje putovanje po Balkanu i evropskom delu Rusije naziva putem „po divljoj Evropi”, a predele koje je posetio „divljim zemljama između Jadranskog i Crnog mora koje žive u bezakonju”, i „žarištima kriminala i hajdučije". Gof i Foset (Goff/Fawcett) u beleškama o Makedoniji pominju „nezreli, neprosvećeni intelekt” makedonskih seljaka, a o karakteru Makedonaca kažu: „Represija i potpuni nedostatak obrazovanja ... stvorili su lukavost i prirodnu sklonost ka divljaštvu”. H. N. Brejlsford (H. N. Brailsford) u sličnom tonu nastoji da dâ sintetički osvrt na narode Balkana: „Pokušao sam da, koliko to jedan Evropljanin može, budem tolerantan i prema hrišćanima i prema Turcima, imajući stalno na umu razliku između normi koje vladaju na Balkanu i onih u Evropi. U zemlji u kojoj seljak ore noseći pušku na leđima, gde vlastodršci ostaju na vlasti zahvaljujući sposobnosti da po potrebi i ubijaju, gde se pretpostavlja da hrišćanski crkveni velikodostojnici organizuju politička ubistva, život ima samo relativnu vrednost, a ubistvo donosi samo relativnu krivicu. Po krvoločnosti se rase na Balkanu međusobno ne razlikuju mnogo - one su proizvod vekovne azijatske vlasti”. O evoluciji stavova i promeni naklonosti Meri Daram prema pojedinim balkanskim narodima opširno piše Svetozar M. Ignjačević u „Kopernikanski obrt (Meri Edita Daram)", Zemlja čuda u izlomljenom ogledalu (ponovo): Jugoslovenska tematika u modernoj engleskoj književnosti, Beograd, Filološki fakultet i Narodna knjiga, 2000, str. $7-58$. 
po dva segmenta - prvi se odnosi na period zatišja u borbama u proleće i leto 1915. godine, a drugi na povlačenje preko Srbije, Crne Gore i Albanije, u jesen i početkom zime iste godine. Takođe, oba segmenta ovih putopisa premrežena su osvrtima autora na sveukupnu političku situaciju u Evropi zahvaćenoj Prvim svetskim ratom i naročito na, po njihovom mišljenju, sramni izostanak podrške Saveznika srpskoj vojsci. Zanimljivo je napomenuti da su bračni par Askju i Mejbel Sinkler Stobart došli u Srbiju u različitim svojstvima, ali sa sličnim pobudama - da pomognu srpskom narodu u jednom od najvećih iskušenja u njegovoj istoriji. Alis Askju (1874-1917) i Klod Askju (1865-1917) bili su književnici koji su u koautorstvu pisali romane i pripovetke. Prijavili su se za odlazak u Srbiju i bili u sastavu Prve britanske poljske bolnice, a kasnije su se priključili Drugoj armiji vojvode Stepe Stepanovića. Imali su zadatak da kao ratni reporteri opišu neposredno iskustvo rata na Balkanu, a bili su i specijalni izveštači britanskih novina Daily Express. Za razliku od njih, Mejbel Sinkler Stobart (1862-1954) pre dolaska u Srbiju već je imala ratno iskustvo. Ova energična žena, osnivač Mobilne ženske jedinice za bolesne i ranjene (Women's Sick and Wounded Convoy Corps, 1912) i Lige ženskog nacionalnog servisa (Women's National Service League, 1914), bila je upravnica ratne bolnice u Balkanskom ratu u Bugarskoj, da bi po izbijanju Prvog svetkog rata osnovala bolnicu najpre u Briselu, a potom i u Serburu, u Francuskoj. Radeći u Francuskoj, čula je vesti o epidemiji tifusa u Srbiji i o tamošnjoj potrebi za medicinskim osobljem, jer je trećina srpskih lekara umrla od tifusa ili na frontu. Stobartova ostavlja bolnicu u Šerburu u sigurnim rukama i odlazi u London, gde ju je Srpski potporni fond zamolio da organizuje bolnicu i stane na njeno čelo.

Putopisi Askjuovih i Stobartove - prvi pisan kao primarni zadatak tokom boravka u Srbiji, a drugi kao prateća aktivnost najpre upravnice bolnice u Kragujevcu, a tokom povlačenja zapovednice u činu majora Leteće poljske bolnice i jedne kolone srpskih vojnika - otkrivaju nekoliko stvari o njihovim autorima: ličnu hrabrost i spremnost na odricanje, poštovanje prema srpskim vojnicima i oficirima i empatiju prema čitavom srpskom narodu, nastojanje da nešto saznaju o srpskoj istoriji kako bi lakše razumeli tragična dešavanja čiji su svedoci bili, 
uzdizanje iznad imperijalne oholosti i otvorenost za prepoznavanje univerzalnih ljudskih (i nacionalnih) vrlina, kakve su duhovna snaga i sposobnost žrtvovanja za ideale. Takav pristup, po prirodi stvari, negira i odbacuje diskurs balkanizma njihovih prethodnika i savremenika, nudeći izbalansiran i duboko humani pogled na jedno od najtragičnijih poglavlja srpske istorije. Cilj ovoga rada jeste da ukaže na primere uvažavanja, poštovanja, pa i divljenja prema Srbima u ova dva ratna putopisa.

\section{ZATIŠJE U PROLEĆE I LETO 1915. GODINE}

Period zatišja u proleće i leto 1915. godine u putopisu bračnog para Askju opisan je u prvih pet od ukupno sedamnaest poglavlja. Ovaj segment pokriva putovanje brodom Saidija iz Engleske do Soluna, opservacije o multikulturalnosti Soluna i putovanju vozom do Skoplja preko Đevđelije, Strumice i Velesa. U Skoplju, gde su proveli šest nedelja, Askjuovi upoznaju Branislava Nušića, tada upravnika Srpskog pozorišta, a general Damjan Popović, komandant vojnih trupa Novih oblasti, Kloda Askjua imenuje za počasnog oficira srpske vojske, koji od tada sa ponosom nosi srpsku uniformu. Iz Skoplja Askjuovi odlaze na izlet na Kosovo, u Gračanicu, gde prisustvuju živopisnom venčanju, i u Tetovo, koje opisuju kao još uvek duboko turski grad u odnosu na Skoplje, već zahvaćeno procesima modernizacije. Premeštanje Prve britanske poljske bolnice u Mladenovac značilo je i dolazak Askjuovih u ovu varošicu iz koje su nekoliko puta posetili Beograd, ,jedini grad u Srbiji koji liči na našu predstavu o tome kako grad treba da izgleda" (AskJu, A. i K., 2012: 78). U Mladenovcu ostaju do kraja septembra, kada kreću u Pirot, gde se srpska vojska koncentrisala za slučaj bugarskog napada. Njihov odlazak u Pirot predstavlja početak iscrpljujućeg tromesečnog putovanja, tokom kojeg su bili učesnici i svedoci povlačenja srpske vojske kroz Srbiju, Crnu Goru i Albaniju.

Odmah po iskrcavanju u Solunu Askjuovi se znatiželjno raspituju o događajima tokom dve nedelje koje su proveli ploveći iz Engleske, i saznaju za očekivanja da se Rumunija, Grčka i Bugarska pridruže 
Saveznicima u borbi protiv Austrougarske. „Tih dana zanosili smo se ružičastim snovima”, zapisaće oni kasnije i dodati: „Politika kako smo je mi videli izgledala je tako ostvarljiva da smo njenu realizaciju primali zdravo za gotovo" (2012: 26). Askjuovi beleže i dirljivo uverenje svoga saputnika iz voza za Skoplje da će saveznici, pogotovu Engleska, Srbiji priteći u pomoć protiv Bugara čiji se napad očekivao, ,jer je Srbija svojim položajem, glavna brana tevtonskim aspiracijama prema Istoku. Pustite da Srbija propadne, i Engleska će predati ključeve za Carigrad, Bagdad, Egipat i Indiju” (2012: 38). Događaji na terenu pokazali su, međutim, da je usledio jedan kratak i ne naročito uspeo francusko-britanski pokušaj da Srbiji upute pomoć koja je išla prugom dok je nisu zauzeli Bugari i da je do okršaja Saveznika sa Bugarima došlo kod Strumice, ali da su, usled bugarskog zauzimanja Štipa i napredovanja ka Prilepu, Saveznici morali da se povuku sve do Soluna.

U poglavlju o boravku u Skoplju Askjuovi prvi put beleže ono što su saznali o srpskoj srednjovekovnoj istoriji - o caru Dušanu i njegovom krunisanju u tom gradu, o Dušanovom nasledniku Urošu koji je stradao od Vukašina, o caru Lazaru, Kosovskoj bici i Lazarevom opredeljenju za carstvo nebesko, o srpskom vojvodi Milošu koji je ubio turskog sultana Murata i o kraljeviću Marku, koga nazivaju „srpskim kraljem Arturom" i tvrde da bi romantične priče o njemu mogle poslužiti kao građa Maloriju ili Tenisonu. Boravak u Mladenovcu koriste da ostave zapis o jednom savremenom primeru patriotizma. Reč je o stanovnicima obližnjeg zabačenog sela Banjani koji nisu na frontu - o ženama, deci i muškarcima starijim od šezdeset godina - koji se ponose time što je čitav mlađi naraštaj mobilisan i svesni su da je najveća dužnost ona prema „majci Srbiji”. Ovo je jedno od retkih, ako ne i jedino mesto u putopisu, u kojem, čini se, mimo svesne volje Askjuovih, ipak provejava diskurs balkanizma. Opisujući stanovnike ove prilično izolovane seoske zajednice, čija je crkva Svetog Ilije skrivena u stenama jer datira iz turskih vremena, autori navode:

Naši automobili - možda i mi - bili su im čudesni jer su bili vrlo primitivni ljudi; živeli su, jedna hrišćanska zajednica, izolovani u svom selu tokom vekova turske vlasti, neobrazovani ali nezavisni, sa sopstvenim zakonima. [...] Ima mnogo takvih sela u staroj Srbiji, sela koja su bila „otkrivena” tokom 
poslednje tri godine, čiji žitelji su skoro mogli biti na društvenom nivou nekog plemena iz Centralne Afrike. Oni, međutim, imaju svoje tradicije koje su prenošene sa oca na sina, svoju osobenu etiku, i to ih je održavalo na višem nivou. Ali pre svega, oni nisu nikada zaboravili da su Srbi. (2012: 62)

U nastavku, uz nemalo divljenje, pominju pobedu srpske vojske u Cerskoj bici i obeležavanje njene prve godišnjice u Mladenovcu, gde su imali priliku da vide najveće srpske vojne zapovednike - vojvode Stepu Stepanovića, Radomira Putnika i Živojina Mišića - dok u poglavlju posvećenom Beogradu svojim čitaocima nastoje da objasne prilike koje su dovele do ubistva kralja Aleksandra Obrenovića i kraljice Drage, i do sarajevskog atentata, te da srpski narod ne zaslužuje pogrdna imena niti prezir Zapada zbog tih događaja. Askjuovi pominju i srpske uspehe u Balkanskim ratovima, kao i veliku ljubav srpskog naroda prema kralju Petru I Karađorđeviću, starom i skromnom vladaru koji je jahao na čelu svojih trupa tokom povlačenja preko Albanije. U prvim poglavljima putopisa Askjuovih jasno su vidljivi entuzijazam i naklonost prema Srbima koji su ih i inspirisali da, čitajući u engleskoj štampi o teškoj situaciji u Srbiji u zimu 1914-15. godine, otputuju tamo i „rad[e] za tu hrabru, malu zemlju” (2012: 29).

Putopis Stobartove sadrži unutrašnju podelu na pet delova i ukupno četrdeset šest poglavlja, za razliku od putopisa Askjuovih, čijih je sedamnaest poglavlja dato u kontinuitetu. Pripovedanje o dolasku u Srbiju i periodu zatišja u proleće i leto 1915. godine Stobartova započinje u četvrtom poglavlju prvog dela (i nastavlja kroz čitav drugi deo, poglavlja 11 do 17), pošto čitaoce prethodno ukratko izvesti o svom angažovanju u Balkanskom ratu u Bugarskoj i bolnicama koje je osnovala u Briselu i Šerburu. Mirnodopski segment putopisa Stobartove fokusira se na rad bolnice u Kragujevcu, na ugledne ličnosti koje su je posećivale (princ Aleksandar Karađorđević, pukovnik dr Lazar Genčić, major dr Protić, pukovnici Harison i Hanter), na austrijsko bombardovanje Kragujevca i epidemiju tifusa koja je odnela nekoliko žrtava među bolničkim osobljem, i na čak šest dispanzera koje je osnovala - u Natalincima, Lapovu, Rudniku, Vitanovcu, Rekovcu i Ovčar Banji - kada joj je bilo predočeno da postoji i velika potreba za lečenjem civilnog stanovništva. Već iz prvih redova Stobartove progova- 
ra energičan i osoben ženski glas. ${ }^{2}$ U predgovoru svome putopisu ova humanitarna radnica i sifražetkinja postavlja tezu da je Prvi svetski rat čovečanstvo doveo do raskršća na kojem jedan put vodi u evoluciju, a drugi u devoluciju - u materijalizam, oličen u militarizmu. „A ja verujem da militarizam može da bude pobeden samo uz pomoć Žene. U zemljama u kojima Žena ima najmanje uticaja militarizam je najdominantniji. Militarizam je razularena muževnost" (SтоваRт 2016: 7). U takvoj konstelaciji sveta Stobartova nastoji da definiše ulogu žene u dotada najvećem ratu u istoriji čovečanstva:

Dakle, militarizam znači dominaciju principa da je izazivanje smrti, u nekim prilikama - u mnogim prilikama - korisnije nego očuvanje života. Militarizam je, bar u jednoj zemlji, dostigao vrhunac, i verujem da je to zato što mi žene osećamo u duši da život ima smisla i vrednost, kojima preti propast u militarizmu, da ovog trenutka instinktivno tražimo udeo u kontrolisanju onih ljudskih života za koje nas je Priroda posebno učinila odgovornim. [...]

Dakle, demonstriranje sposobnosti žene da preuzme koristan udeo u nacionalnoj odbrani mora se dati u radu u kome je cilj očuvanje a ne uništavanje života. Takav posao je nega bolesnika i ranjenika. (2016:15)

Medicinska jedinica Stobartove brojala je četrdeset pet članova - pet lekarki, osamnaest medicinskih sestara i pomoćno osoblje - a bolnica je smeštena na kragujevačkom trkalištu izvan grada i organizovana pod šatorima. Bilo je ukupno šezdeset šatora i imali su razne namene - za prijem pacijenata, za operacije, za bolesničke postelje i ordinacije, za rentgen i apoteku, za kuhinje i kupatila. Po dolasku u Kragujevac i ljubaznom prijemu na koji su naišli, Stobartova beleži pohvalne reči o srpskim oficirima:

Bilo je divno otkriti da su srpski oficiri, i sanitetski i vojni, kulturni ljudi, inteligentni i simpatični. Odmah sam znala da će mi se svideti. Većina je govorila nemački, neki su govorili francuski, ali su svi mogli da razgovaraju tečno na jednom ili drugom jeziku, pored, naravno,

2 Iako su kao autori Opustošene zemlje potpisani Alis i Klod Askju, Klod Askju u Predgovoru navodi da on beleži događaje „onako kako smo ih videli i razumeli na licu mesta" (2012: 19). 
svog. ${ }^{3}$ Čovek se uvek u inostranstvu seti da su svi drugi narodi obrazovaniji od nas. (2012: 33)

Osim o poštovanju prema srpskim oficirima, ova zapažanja, utemeljena na iskustvu iz prve ruke, svedoče i o otvorenosti autorke prema ljudima u čiju je zemlju došla, verovatno opterećena negativnom slikom koju je o njoj dobila u Engleskoj. Uprkos tome, ne prihvatajući je zdravo za gotovo, potrudila se da otkrije kakvi su ljudi Srbi, a rezultat toga truda je spoznaja potpuno suprotna od one sa kojom je došla. Stoga su susreti sa ranjenicima tokom prvih nekoliko dana rada u bolnici autorki dovoljni da stvori i širu sliku o srpskom vojniku i svojim pacijentima, sliku koja se može razumeti i kao njena implicitna polemika sa prethodnicima i savremenicima u čijim delima dominira diskurs balkanizma.

Odmah sam shvatila da je utisak, koji i danas preovlađuje u zapadnoj Evropi, o ratobornosti srpskog naroda pogrešan.

Prosečni srpski seljak-vojnik nije ratoboran, divlji, divljak koji voli borbu, kako ga tako često predstavljaju. On ne voli ratovanje, ali voli svim oduševljenjem pesničke prirode svoju porodicu, svoj dom, svoje hektare zemlje i svoju zemlju. Borio se mnogo u prošlosti ali da bi odbranio ono što ima i što ceni. Niko ne može da optuži srpskog vojnika za kukavičluk, a ipak, ova nesklonost ratovanju i njegova ljubav prema domu su toliko izraženi da je bilo lako razlikovati po žustrom koraku i vedrom izrazu lica, ili po sporom hodu i depresivnom izrazu, da li vojnik u sivoj uniformi, koji sa rancem ide drumom ide kući ili - pošto mu je isteklo desetodnevno odsustvo - ide još jednom $u$ komandu (na front).

Naši ranjenici su bili najšarmantniji pacijeni koje možete zamisliti, i uvek je bilo zadovoljstvo ući u odeljenje i razgovarati sa njima. Bili su žive inteligencije, sa divnim smislom za humor, i potpunim odsustvom vulgarnosti ili prostakluka. Bili su veoma učtivi, puni obzira i taktični u ponašanju prema sestrama, i prema nama ženama u celini, i tako puni ljubavi i zahvalnosti za ukazanu pomoć, da je bilo teško shvatiti da oni nisu oficiri već seljaci, koji malo poznaju svet van sopstvene nacionalne istorije. (2016: $36-7$ )

3 Alis i Klod Askju takođe beleže, još prilikom boravka u Skoplju, da svi govore francuski ili nemački jezik (2012: 47). 
Milica Spremić Končar: Opustošena zemlja: dva engleska svedočanstva...

Zanimljivo je da Askjuovi potvrđuju negativan stav o Srbima prisutan na Zapadu i pobijaju ga u tonu sličnom Stobartovoj:

Seljak se ponosi svojim domom i svojom zemljom i više voli svoje metode od svih za koje mu kažu da su bolji. Vredan je, ali ne voli da ga požuruju; on nikako nije 'zlikovac', kako su nas u Engleskoj naveli da poverujemo nasuprot, gostoljubivo će vas ugostiti ako ga posetite u njegovom domu, i ako to učinite, uvidećete da su njegove navike i običaji umnogome isti danas kao stotinama godina unazad, i veoma zanimljivi. (2012: 128)

Predani rad u bolnici i organizovanje dispanzera, susreti sa uglednim ličnostima i običnim ljudima, spremnost da savlada osnove srpskog jezika i upozna se sa lokalnim običajima vrlo brzo su Mejbel Stjuart učinili omiljenom i poštovanom među Srbima, čiju je zahvalnost neprestano osećala. Upečatljivi su njeni zapisi o guslama i pevanju o uvek tragičnoj srpskoj istoriji, o slavi i slavskim običajima kod majora Protića i predsednika opštine Lapovo, o pomoći ukazivanoj civilnom stanovništvu u dispanzerima i spremnosti naroda da se leči, o ljubaznosti predstavnika lokalne vlasti i prostodušnosti seljaka, o crkvi na Oplencu, ali i o prirodnim lepotama Srbije i izdašnim plodovima njenih polja i voćnjaka. Kada stignu vesti o obnavljanju sukoba i mobilizaciji srpske vojske, pukovnik Genčić Stobartovoj saopštava da im je potrebna pomoć, i pita je da li bi pratila srpsku armiju kao leteća bolnica za front. Na njen potvrdan odgovor usledi još jedan kompliment - zamoljena je da preuzme i zapovedništvo nad jednom kolonom srpskih vojnika, vozara zaprežnih kola i konjovodaca.

Dok sam slušala ove reči pitala sam se da li sam u Srbiji, zemlji koja je stotinama godina bila pod turskom vlašću, i izložena turskoj tradiciji u pogledu žena. Rekla sam da cenim ukazano poverenje i izrazih nadu da ću se pokazati dostojna njega, i zadovoljstvo što mogu makar malo da pokažem simpatiju koja postoji između našeg i srpskog naroda. (2016: 126)

Pošto je postignut dogovor o daljim koracima, bolnica se podelila - jedan deo, pod upravom Stobartove, biva preimenovan u Leteću poljsku bolnicu i pridodat Šumadijskoj diviziji pukovnika Božidara Terzića, a drugi ostaje u Kragujevcu, pod upravom dr King-Mej. Kao i Askjuovi iz Mladenovca, i Stobartova iz Kragujevca, sa poljskom bolnicom i 
kolonom vojnika pod svojom komandom, kreće vozom u Pirot, predosećajući da slede teški dani, ali kao i toliki drugi, nesposobna da pojmi razmere predstojećih patnji.

\section{Povlačenje Preko SrbiJe, Crne Gore i Albanide}

Povlačenje preko Srbije, Crne Gore i Albanije odvija se u nekoliko etapa. U putopisu Askjuovih ono je opisano u poglavljima 6 do 16, a u putopisu Stobartove zauzima čitav treći deo, odnosno poglavlja 18 do 45. Askjuovi se kreću od Pirota ka Nišu, Prokuplju, Prištini, Peći i Prizrenu, a onda kroz Crnu Goru i Albaniju, dok bolnica i kolona Stobartove u kretanju kroz Srbiju imaju nešto drugačiju maršrutu, prilagođenu potrebama zbrinjavanja ranjenika. Oni iz Pirota preko Knjaževca stižu u Niš, potom u Veliku Planu, Smederevsku Palanku, Jagodinu i Varvarin, a odatle preko Blaca do Prištine, Peći i dalje, kroz Crnu Goru i Albaniju. Prolazak kroz Srbiju obeležava još uvek prisutna nada u pomoć Saveznika i neizvesnost u pogledu daljeg pravca kretanja, dok putovanje kroz Crnu Goru i Albaniju odlikuju ne samo užasne fizičke patnje, nego i svest o sveobuhvatnoj tragediji srpskog naroda. Svedočanstvo o povlačenju zauzima centralnu poziciju u oba putopisa, sadrži tri glavne teme - divljenje prema Srbima, negostoljubivost Crnogoraca i Albanaca, i izdaja Saveznika - i usputne primedbe o oskudici tokom putovanja i surovosti prirode.

\subsection{DivlJenje PREMA Srbima}

Kada je o prvoj temi reč, Askjuovi i Stobartova tokom boravka u Srbiji i povlačenja sa srpskom vojskom postaju svesni pogrešne i negativne slike koju Zapad generiše o Srbima, narodu vrednom poštovanja i divljenja, što ističu na više mesta u svojim delima. Askjuovi hvale spremnost Srba da pristupe vojsci i bore se za svoju zemlju, zbog čega su neki došli čak iz Amerike, i pominju potresnu sudbinu devojke koja želi u rat jer su joj oba brata poginula, a otac je suviše star da bi 
se borio (2012: 93). Kada u Pirot stigne naređenje o povlačenju Prve britanske poljske bolnice, pacijenti to iskušenje podnose „sa stoičkom hrabrošću karakterističnom za Srbe" (2012: 105), a na početku najsurovije etape povlačenja, od Peći do Andrijevice, Askjuovi beleže: „Što se nas tiče, uvek ćemo biti zahvalni što smo jahali s vojskom jer možemo da damo svedočanstvo očevidaca o izvanrednoj disciplini koja je vladala - uzvišena izdržljivost” (2012: 176). Prispeće u Andrijevicu nije, međutim, donelo ni hranu ni odmor, čemu se iznurena srpska vojska nadala. Uprkos tome, sačuvana je prisebnost:

Čudesno je što se suočena sa svim tim srpska vojska ponašala zapanjujuće moralno hrabro. Mora im večito služiti na čast što nisu popustili - kao što su se bojali mnogi njihovi oficiri - nisu se oteli kontroli i pljačkali grad. Umesto toga, stegli su zube, sećajući se časti svoje zemlje, i sa nepobedivom odlučnošću su se spremili da krenu dalje, umorni i neosveženi, na dugi marš, dva puta duži od onog od Peći, i jedva manje težak, ka Podgorici i Skadru. (2012: 179)

Na odmorištu u selu Kućište iznureni Askjuovi - naročito Alis, koja teško hoda jer upada u blato - od nepoznatih Srba dožive dva lepa gesta: dobiju čaj od ljudi koje prolazeći zateknu kako sede pored vatre, a potom se pojavi nekoliko oficira i ustupe im konje „sa karakterističnom srpskom pažnjom i plemenitošću” (2012: 181).

Stobartova beleži da Srbi humano postupaju prema nemačkim zarobljenicima $^{4}$ (2016: 157) i hvali plemenite osobine srpskih oficira u mnogo težim okolnostima od onih kada ih je prvi put srela u Kragujevcu. Pominje da su „izuzetno učtivi” jer im pomažu da povrate svoje mesto u koloni, a dvaput ih naziva i kavaljerima. Prvi put, kada po prispeću u Varvarin dobije poruku da jedan artiljerijski major čeka nekoliko sati da je pozdravi. Ispostavi se da se znaju iz Kragujevca jer je jednom posetio njenu bolnicu.

Čini se zbilja da srpski oficiri bez obzira u kakvim se okolnostima nađu, uvek čine pravu stvar u pravom trenutku. Bili su pravi kavaljeri, ne sa kavaljerstvom koje hita da vam otvori vrata da vas pusti napolje, već sa kavaljerstvom koje ostavlja vrata otvorenim da uđete. (2016: 186)

4 Isto pominju i Askjuovi, na str. 190. 
Znatno kasnije, kada su već stigli u Podgoricu i našli prenoćište u školskoj zgradi, autorka beleži „šarmantan gest tipičan za srpsko kavaljerstvo", kada joj major sa kojim su delili učionicu pretvorenu u spavaonicu, ponudi da podele prostran dušek, kako ne bi spavala na podu. „Srpski majori ne hrču, stoga prihvatih ponudu, i uzdignuti kraljevski iznad drugih, major i ja smo spavali jedno pored drugog. Ali sve je izgledalo tako prirodno da se nismo čak ni nasmešili. Volela bih da ponovo sretnem majora" (2016: 275). Stobartova je duboko zadivljena i mirnoćom sa kojom Srbi podnose tragediju:

Ali dostojanstvenost i organizovanost sa kojim je izvedeno povlačenje srpske armije od početka do kraja bili su izvanredni. A tišina! Sat za satom, danju noću, danju noću, nedelju za nedeljom, hiljade vojnika se vuklo umorno pored svojih sporih volova, ili sa svojim pešačkim pukovima, ili terali svoje topovske kare, ili su, kao konjica, jahali ćutke. Nije bilo smeha, pevanja, razgovora; tišina pogrebne povorke, što je ona i bila; tišina koju bi prekidala samo vika vozača na volove: „Cvetko! Belac! Napred! Desno! Levo!", i neprekidno tandrkanje točkova kola, koje je zvučalo kao udaranje besnih talasa o daleku šljunkovitu plažu. (2016:187)

Prilikom prelaska Kosovog polja i dolaska u Prištinu autorka ostavlja zapis o Kosovskoj bici, Lazarevom izboru carstva nebeskog i značenju ovog događaja za Srbe, a onda poražavajuću poziciju srpske vojske kojoj svedoči efektno naziva novim porazom od saveznika istih onih Turaka sa kojima se knez Lazar borio pet stotina godina ranije, porazom u kojem vojska ipak nije izgubila dušu. Prošavši jedan deo najsurovije etape puta - crnogorske planine pre ulaska u Podgoricu - po kiši i surovoj hladnoći, gledajući iznemogle ljude kako padaju i umiru na uzanoj stazi, Stobartova svojim čitaocima nastoji da predoči kakva ih sila tera na žrtvu koju podnose:

Ideja je bila ista kao ona za koju su srpski vojnici položili svoje živote na Kosovu, ideja koja u sebi nema ničega od vulgarnog osvajanja ili agresije, ideja da duša Srbije mora da bude slobodna, da ostvari svoje spasenje. Dom, porodica, čak i zemlja, ne znače ništa ako duša Srbije nije slobodna. Dom, porodica, čak i zemlja, moraju da budu žrtvovani ako treba da bi duša Srbije bila slobodna. (2012: 273) 


\subsection{Negostoljubivost Crnogoraca i Albanaca}

Druga tema - negostoljubivost Crnogoraca i Albanaca - takođe prožima oba putopisa. Askjuovi je nagoveštavaju još u poglavlju o boravku u Pirotu, kada pominju gazdaricu koja nije htela da im naplati kiriju, navodeći da je to samo jedan od primera ljubaznosti na koju su naišli u Srbiji, i dodavši: „Kasnije ćemo saznati, na našu štetu, koliko se Crnogorac u ovom pogledu razlikuje od Srbina” (2012: 91). Slično iskustvo imali su i u Kuršumliji, gde ih je porodica mesnog apotekara opskrbila hlebom, sirom, kobasicom i kafom, takođe odbivši da uzmu novac: „Bili su dobrodušni, ljubazni ljudi, pravi Srbi, i kasnije smo često imali priliku da uporedimo njihovu gostoprimljivost sa grubim i gramzivim ponašanjem Crnogoraca” (2012: 138). U jednom albanskom selu na putu od Đakovice do Peći negostoljubivi starešina odbija da im preporuči kuće u kojima bi mogli da prenoće, pa provode noć u kolima, izloženi opasnosti od napada Albanaca čija im se izvidnica približi, ali ipak odustane od dejstva, pogrešno procenivši na osnovu upaljenih vatri da je u blizini stacioniran veći broj logora srpske vojske. Posle ovog iskustva i svedočanstava drugih ljudi Askjuovi navode da su „stalno videli - ili uobražavali - pretnju na licima Arnauta na ulicama i osećali da će biti bolje da što pre odemo" (2012: 171). Nagoveštaji nepovoljne slike o Crnogorcima materijalizuju se po prispeću u Andrijevicu, gde su „bili zapanjeni cenom hleba i činjenicom da je hrane bilo tako malo" (2012: 191) i prilikom noćenja u jednoj kući u selu Bare koje je koštalo ,gotovo koliko bismo platili za apartman u Ricu ili Karltonu” (2012: 195).

Zapažanja Stobartove su slična - Crnogorci su bili nevoljni da im prodaju hranu, a kada su to činili cene su bile basnoslovne, poput proje plaćene osamnaest šilinga (2016: 265). Jedan seoski starešina zabranjuje meštaninu sela da vojsci proda hleb i seno, a tek kada ga Stobartova upozori da će priču o njemu proslediti engleskim novinama, on menja stav i i tvrdi da se nisu dobro razumeli (2016: 267-8). Autorka ipak beleži i primere lepšeg ophođenja prema srpskoj vojsci, kakav je dozvola jednog crnogorskog policajca da prespavaju na blatnjavom podu njegove sobe (2016: 269). Prešavši u albanske planine, 
bolnica i kolona Stobartove suočavaju se sa istim teškoćama - Albanci im ne dozvoljavaju da provedu noć na njihovim njivama i neće da im prodaju hranu, ali svakoga od njih moguće je potkupiti novcem. Dospevši u jedno drugo selo, pokucaju na vrata kuće u kojoj su živele neke žene. Kada ih zamole za prenoćište u jednoj od soba, žene briznu u plač, rekavši da su kuću njihovog komšije opljačkali vojnici i da se plaše vojske. Ovde do izražaja dolaze duhovitost i ironija Stobartove:

Na kraju, pošto smo osušili njihove suze novcem, rekoše da će primiti žene, ali da muškarci moraju smesta da produže. Naravno, nismo hteli da prihvatimo to i pošto smo već bili mokri do gole kože, pomislili smo da je bolje da se zagrejemo hodajući i da pokušamo da stignemo do sledeće vojne postaje, za koju nam rekoše da je udaljena samo dva sata hoda. (2016: 284)

\subsection{IZDAJA SAVEZNIKA}

Treća tema - izdaja Saveznika - premrežava oba putopisa, od prvog do poslednjeg poglavlja. U ranim poglavljima javlja se najpre kao uverenje u njihov skori dolazak i iščekivanje takve vesti, sa protokom vremena i njenim izostankom prelazi u nadu da je odlaganje privremeno, dok konačno saznanje o sramnoj izdaji srpske vojske i kod Askjuovih i kod Stobartove rađa osećaj krivice i dubokog razočaranja u sopstvenu naciju. Boraveći u Pirotu, i pored vesti o padu Beograda, Askjuovi, još uvek puni samopouzdanja, čitaju u engleskim novinama izveštaje o govorima u engleskom i francuskom parlamentu i prevode lepe reči srpskim prijateljima iz štaba, koje ovi dočekuju uzvicima odobravanja. Klod Askju će kasnije zapisati: „Nećemo se nikada setiti bez osećanja stida našeg samouverenog oduševljenja i kako smo se ponosno hvalili čašću naše zemlje" (2012: 98). Očekivalo se, naime, svakoga dana da Saveznici dođu u Niš, gde im je bila pripremljena i dobrodošlica. „Niš je uzalud istakao zastave: tužna je činjenica da je, kada je grad pao posle nekoliko nedelja, još uvek bilo kuća na kojima su bile istaknute zastave Saveznika, koje su podignute u čast događaja koji je pripadao carstvu maštovite nade" (2012: 104). Veoma je sličnog tona i zapis Stobartove: 
Milica Spremić Končar: Opustošena zemlja: dva engleska svedočanstva...

Stigli smo u Niš u deset pre podne i videli da je grad zbilja okićen zastavama u čast dolaska Saveznika! Pretpostavljali smo da sada neće stići, i mnogo nedelja potom te zastave dobrodošlice visile su metaforično u našim srcima, stvarajući ono neopisivo osećanje pomešane nade, razočaranja i poniženja koje smo osećali dok smo se toga dana vozili kroz Niš. (2016: 149)

Askjuovi beleže i razgovor sa jednim starim gospodinom, vlasnikom radnje mešovite robe u Nišu, svesnim da je pomoć Saveznika izostala. „Ipak, nije bilo gorčine u njegovom glasu dok je govorio o tome. ,Ne znam zašto nas je vaša velika zemlja izneverila,' rekao je sa mirnom rezignacijom, ali mora da postoji neki razlog - neki jak razlog - koji ćemo razumeti kasnije" (2012: 123). Sedmodnevni boravak Askjuovih u Prokuplju još uvek je ispunjen nadom u savezničku ofanzivu na jugu, a i oficiri imaju naređenje da hrabre vojnike nadom u dolazak Saveznika, iako su svesni da ih obmanjuju. O svojim nadama i trenutku kada su zauvek nestale Askjuovi pišu:

Isto je bilo i sa nama: najpre smo verovali pričama. U stvari, ne bismo žurili da odemo iz zemlje čak i da smo mogli da učinimo to lako i bezbedno, jer nismo mogli da odbacimo nadu da će se ratna sreća preokrenuti i da će srpska vojska pobedonosno da juriša preko teritorije koju je napustila, i da ćemo imati privilegiju da sudelujemo u njenom trijumfu. Tek kada smo napustili Peć napustili smo svu nadu. (2012: 125-6)

I zaista, prispeće u Prištinu i simbolika Kosova Polja još jednom su podstakli snove u mogućnost preokreta.

Na istorijskom polju Kosovu koncentrisaće se tri armije, i možda će, ako se stvari na jugu budu dobro razvijale, doći do spajanja Srba i Saveznika. Bilo bi veličanstveno, tvrdili smo, kada bi Kosovo još jednom bilo poprište jedne strašne bitke, Kosovo koje je već središte svega što je najbolje u srpskoj legendi i priči, i kada bi na Kosovu Srbija odbranila svoju čast i ponovo dobila ono što je njeno. (2012: 142)

Nasuprot nadama, zapisi Askjuovih o Saveznicima završavaju se u tamnim tonovima, osvrtom na dva događaja iz Prizrena. Prvi je susret sa generalom Popovićem, poznanikom iz skopskih dana, za koga su čuli da ga zvanično krive za pad Skoplja, iako je istina da su za odbranu grada ostavljene malobrojne trupe srpske vojske, pošto se verovalo da 
Saveznici Skoplje neće ostaviti nezaštićenim. Drugi događaj svedoči o negativnom stavu prema Srbima i diskursu balkanizma dominantnom u Engleskoj, i pokazuje u kojoj su meri ratni putopisi Askjuovih i Stobartove osobene pojave u engleskoj izdavačkoj produkciji i javnosti onoga vremena. Zato će ovde u celini biti naveden drugi događaj koji beleže Askjuovi:

Za stolom menze Vrhovne komande jedan visoki engleski zvaničnik je izneo neke opaske koje su me jako iznenadile - pošto su došle od njega.

„Vi, naravno, znate,” rekao je, „da se Srbi uopšte nisu borili. Ne dozvoljavaju da ratni dopisnici dođu na front - a to je razlog."

Govorio sam o ranjenicima u našoj bolnici u Pirotu; pomenuo sam žestoke borbe kod Leskovca, Mramora, Kačanika, i drugde.

Slegao je ramenima. „Neki ljudi moraju da budu povređeni kad naokolo lete šrapneli," rekao je.

Svako ima pravo na sopstveno mišljenje. Lično mislim da je bilo puno dokaza, isuviše dokaza, u korist Srba; ali ako neko želi da odbaci očiglednu činjenicu, na volju mu da to čini. Da li je, međutim, opravdano da prihvati gostoprimstvo, kao akreditovani gost, zemlje koju tako očigledno ne voli? To je situacija, ali ako ne mogu da zaboravim reči, ne mogu ni da zaboravim mesto gde su izrečene. (2012: 156)

Pitanje gde su Saveznici prožima čitav segment putopisa Stobartove posvećen povlačenju srpske vojske. Prisutno je u beleški iz Pirota da su Saveznici stali na stranu Bugarske pred početak neprijateljstava između Bugarske i Srbije (2016: 137) i u još postojećoj nadi u pomoć Saveznika kada u selu Dobri Do prvi put dobiju naredbu za povlačenje, a autorka se glasno pita „Gde su francuske i engleske trupe?” (2016: 161) kada u okolini Smederevske Palanke čuje da su Bugari zauzeli Vranje, da je srpska vlada napustila Niš jer su im Bugari za petama, a da su Nemci u Valjevu i na svega tri kilomerta od njih, u Mihajlovcu. Glasine o dolasku Saveznika proređuju se sa vestima o nemačkom zauzimanju Kragujevca i preuzimanju dispanzera Stobartove na Rudniku, a njen osećaj nelagode kulminira kada joj u okolini Kruševca komandant divizije tiho saopšti da su Niš zauzeli Bugari. 
Milica Spremić Končar: Opustošena zemlja: dva engleska svedočanstva...

Gde su, pitali smo se, Francuzi i Englezi? Ali preko njegovih usana nije prešla nijedna ogorčena reč. „Sigurno postoji neki razlog”, bio je njegov jedini komentar. A ja sam mogla da kažem samo ono što sam uvek govorila, „Ne mari, sve ćemo to dobiti jednog dana”, ali ponekad sam gotovo poželela, po prvi put u životu, da nisam Engleskinja. (2016: 190)

Osim sopstvene nelagode, Stobartova često ističe gospodsko ponašanje Srba uprkos izdaji Saveznika. „Ali nikada nisam, tokom tromesečnog povlačenja, čula ni oficira ni vojnika da izgovore neku gorku reč, ili prekor, o tome što Saveznici nisu došli. Uvek bi rekli, sa smirenim dostojanstvom, da postoji dobar razlog zašto još nisu mogli da pošalju pomoć" (2016: 199). Teško probijanje kroz Jankovu klisuru i dolazak u Blace predstavljaju trenutak u kojem se ukazuju stravične posledice izdaje Saveznika.

Misao koja nas je opsedala je još uvek bila, „Da li ćemo se sresti sa Francuzima i Englezima pre nego što nas Bugari zarobe?" Skoplje je već bilo u bugarskim rukama i sada sam po prvi put čula da će, ako nema nade da nam se pridruže Saveznici, armija morati da se povlači preko crnogorskih planina prema albanskom primorju. Ali razgovor se još uvek završavao nadom da će Saveznici doći. (2016: 203)

Nastavak povlačenja ka selu Barbatovcu blizu Kuršumlije i razgovor sa načelnikom saniteta povod su autorki da nešto detaljnije progovori o odnosu Engleza prema Srbima. Mada i sama veruje da Engleska i Francuska ne bi poslale trupe u Solun da nisu imale nameru da pomognu Srbiji, svesna je da je naklonost Engleske prema Srbiji „uzgredna” i da Englezi Srbiju još uvek ocenjuju prema „nesrećnom činu" sarajevskog atentata, te da sa jedne strane preuveličavaju mane Srba, a sa druge preterano uzdižu vrline Bugara. Završnica ovog segmenta pokazuje da je autorka bolno svesna pravog stanja stvari, te zato upućuje apel javnosti svoje zemlje:

Uverenost sa kojom Srbi veruju da će Engleska, kada shvati ideal za koji se Srbija bori, pružiti ne samo mali prst već i celu šaku prijateljstva, dirnula me je gotovo više nego njihove patnje. I ako kao nacija ne ispunimo očekivanja da ćemo mi, koji smo stekli sopstvenu slobodu, pomoći Srbima da steknu svoju, nećemo nikada moći da pogledamo u lice jednu demokratsku zemlju. (2016:207) 
Međutim, sasvim suprotno njenim nadanjima, vrtlog događaja vodi srpsku vojsku dalje na jug, preko Prištine i Prizrena do Peći, gde se pred polazak ka planinama Crne Gore i Albanije, u gotovo poetskom zanosu, Stobartova oprašta od teškog, ali u poređenju sa onim što ih nadalje čeka, iole podnošljivog probijanja kroz Srbiju, i od Saveznika čiju pomoć nisu dočekali.

Zbogom našoj gostoljubivoj poljskoj kuhinji i svemu što joj je pripadalo; zbogom našim šatorima i krevetima i poslednjim ostacima bolničkog rada. I najgore od svega, zbogom svakoj nadi da će Srbija biti spasena.

Jer sada je nestala svaka nada u pomoć Saveznika i otkrivena je sva veličina tragedije srpskog naroda. (2016: 242)

Strahote putovanja preko planina Crne Gore i Albanije Askjuovi i Stobartova sugestivno dočaravaju slikama hladnoće, snega, iscrpljenosti, gladi, iznemoglih volova i konja, ljudi koji od umora padaju i umiru kraj puta, marševa dugih po nekoliko dana, i noćenja u prljavim i hladnim svratištima, ili pak na otvorenom.

Iako su se povlačili sličnom maršrutom, pažnju Askjuovih i Stobartove, uz glavne, zajedničke teme, zaokupljaju i neke druge, sporedne, ali ne i beznačajne. Tako Askjuovi, kao ratni izveštači, nalaze vremena i prilike da prokomentarišu izgled srpskih gradova, pojedinih ulica, hotela, radnji, pijaca, hrane, i da zabeleže poneku skicu razgovora sa lokalnim stanovništvom, dok Stobartova beleži imena manje poznatih sela i zaselaka u kojima su se odmarali, krepili ili noćili, i koncentriše se na stanje u bolnici i poverenoj joj koloni, na ukazivanje pomoći ranjenicima koji su neprestano pristizali sa fronta, na disciplinu i funkcionisanje po zadatom rasporedu. Ako gradovi - po kojima, uostalom, nazivaju svoja poglavlja - Askjuovima pružaju sliku srpskog načina života i svedoče o tradiciji prohujalih vremena, za Stobartovu - čija su poglavlja obeležena samo rimskim brojevima - oni su najpre izvor preko potrebnih zaliha hrane i vode i tačke na kojima se odlučivalo o daljim strateškim potezima. Sa druge strane, autorska podudaranja u razmišljanjima i komentarima česta su i brojna, a posebno se pamte minijature kakve su opaske o srpskom jeziku i upotrebi reči „dobro” (2012: 145; 2016: 53). Iako su Askjuovi i Stobartova u Srbiji boravili u 
isto vreme, verovatno i stigli u Solun istog dana brodom Saidija, ni u jednom ni u drugom putopisu nema indicija da su se sreli i upoznali. Zanimljivo je da Askjuovi znaju za gospođu Stobart i njenu humanitarnu misiju i pominju je u tekstu (2012: 47, 222), a ona njih ne.

Osim o praktičnim detaljima svoga rada, Stobartova na više mesta progovara o egzistencijalnim temama, o pitanju života, smrti i onoga što dolazi posle smrti. Takva razmišljanja, sasvim prirodna u uslovima rata, prvi put se javljaju još tokom plovidbe brodom Saidija ka Solunu, dok posmatra svoje saputnike kako zabavom prekraćuju putovanje.

Koliko će se svih ovih lekarki, sestara, bolničara, administrativnog osoblja, šofera, prevodilaca, vratiti? Neko će biti primljen a drugi ostavljen? Smejući se, pevajući, glumeći, čitajući, igrajući karte, flertujući, svađajući se - koliko njih radi te stvari poslednji put? Koja im je sudbina namenjena, svakoj i svima? Da li smo, kao pomoćno osoblje Srpske armije, plovili u život ili smrt, pobedu ili poraz? (2016: 28)

Ovakvih pasaža ima i kasnije, i u segmentu putopisa iz perioda zatišja, i u onom koji se odnosi na povlačnje. U prvom segmentu pokreću ih sumorni događaji, kakvi su dve smrti od tifusa među bolničkim osobljem, ili naprosto svest da je smrt blizu i pored redovne dnevne rutine u bolnici i dispanzerima, dok su u drugom segmentu putopisa sastavni deo apokaliptične situacije u kojoj se autorka našla sa nešto svojih sunarodnika i čitavom srpskom vojskom.

Dolazak u Skadar označava kraj najteže deonice puta, ali ne i kraj iskušenja srpske vojske. Askjuovi u Skadru provode tri nedelje jer se Alis oporavlja od iznemoglosti u vlažnoj i hladnoj sobi njihovog konačišta, uz vrlo oskudnu hranu. Uz to, Skadar je izložen austrijskom bombardovanju, i Klod samo srećnim spletom okolnosti uspe da izbegne bombu palu na stepenište zgrade u koju se zaputio. Askjuovi polaze zajedno sa Drugom armijom, po dobijenom naređenju da nastave kretanje ka Lješu, u čijoj se blizini, u selu San Đovani di Medova, ukrcavaju na brod za Brindizi 19. januara 1916. godine. U poslednjem, sedamanestom poglavlju putopisa, naslovljenom „Kod kuće”, Askjuovi beleže vesti koje su nakandno dobili, o završetku povlačenja i prispeću Druge armije na Krf, i izriču pohvalu srpskoj vojsci. Stobartova u 
Skadru predaje raport pukovniku Genčiću, koji joj u prisustvu ministra vojnog saopštava da je njihova kolona ,jedina kolona koja je stigla čitava, bez dezertera, posle putovanja koje je, od početka do kraja, iznosilo ukupno oko osam stotina milja" (2016: 288). Dirnuta odanošću osoblja koje je radilo pod njenom komandom i odnosom srpskih vojnika prema ženi-komandantu koji su joj, iako vaspitani u duhu turske tradicije u pogledu odnosa prema ženi, pružili „dragovoljnu poslušnost i odanost koja nije nikada izneverila tokom tri meseca", poglavlje o prispeću u Skadar autorka završava rečima: „ponosim se što sam mogla da učinim makar i najmanju uslugu ovoj srpskoj vojsci, i srpskom narodu, koje volim i poštujem" (2016: 290-1). U Skadru ju je primio prestolonaslednik Aleksandar Karađorđević, posle čega, sa najbližim saradnicima, polazi u San Đovani di Medova, gde se ukrcava u brod za Brindizi, 24. decembra 1915. godine. U pretposlednjem, četvrtom delu putopisa Stobartova rezimira svoje poglede na rat i ulogu žene u njemu, i izražava divljenje prema herojstvu srpskog naroda, dok u petom delu objavljuje pisma zahvalnosti dobijena od pukovnika dr Lazara Genčića i pukovnika Božidara Terzića, sa detaljnim izveštajima o dometima i rezultatima rada njene bolnice.

\section{ZAKLJUČAK}

Ratni putopisi o Srbiji bračnog para Askju i Mejbel Sinkler Stobart dvostruko su dragoceni, jer sa jedne strane svedoče o hrabrosti, nepristrasnosti i požrtvovanju njihovih autora, a sa druge strane o patnji, porazu, istrajnosti i herojstvu srpske vojske. Kada je reč o književnim dometima putopisa, Stobartova ostavlja utisak književno talentovanije iako su se Askjuovi profesionalno bavili pisanjem. Askjuovima je bliže faktografsko beleženje događaja, dok Stobartova poseduje smisao za detalj i uopštavanje, a često u pripovedanje umeće lirske i refleksivne pasaže. Zajednička odlika oba putopisa jeste snažno suprotstavljanje diskursu balkanizma, na više mesta ilustrovano u ovome radu. Završne rečenice i jednog i drugog putopisa efektno sumiraju naklonost 
Milica Spremić Končar: Opustošena zemlja: dva engleska svedočanstva...

autora prema Srbiji ali i njihov sud o velikim silama. Srpski oficir Klod Askju zapisuje ove reči:

I neka se ne zaboravi da je Srbija patila ćutke - njeni izgladneli ljudi se nisu žalili dok su padali i umirali; nisu rekli ništa i Srbija nije rekla ništa. Nikakvi prekori nisu prešli preko njenih bolnih usana. Njen bol je bol nacije čije srce je slomljeno - čiji ponos je slomljen; i suze Srbije su kao krvavi znoj Getsemanskog vrta: ali njena hrabrost - eh, možemo zaista da pustimo našim jezicima na volju kada govorimo o njenoj hrabrosti i njenoj istrajnosti; ona nas može uzdići i uzneti, jer ova mala nacija nije nikad bila slavnija nego u času ovozemaljskog poraza. U očima nemudrih činilo se da je umrla; ali ona se dohvatila besmrtnog života, jer duh Srbije je nepobediv, duša Srbije nije zastrašena.

Zar nema nečeg strašnog u toj pomirenosti - nečeg nezemaljskog - nečeg što uliva strahopoštovanje u dušama drugih nacija? Jer setite se zastava istaknutih u Nišu - zastava istaknutih da dobrodošlicom dočekaju trupe koje nikada nisu došle. (2012: 249-50)

Major srpske vojske Mejbel Sinkler Stobart donosi sledeći zaključak:

Tako je Srbija, koja se poslednja od evropskih nacija razvila, shvatila uvidom kome će se jednoga dana istorija diviti, unutrašnje, pravo tumačenje reči „nacija”. Shvatila je da je životna snaga jedne nacije duhovna snaga, koja ne zavisi od materijalnih uslova egzistencije. [...]

U nekom manje značajnom pogledu Srbija možda zaostaje za ostalim nacijama u zapadnoj Evropi, ali je ispred zapadne Evrope u jednoj stvari, koja je od prave važnosti, stvari koja se ne može kopirati ili naučiti od drugih naroda, i koja je ili urođena ili nedostižna - Srbija je ispred drugih nacija po svojoj sposobnosti da se žrtvuje za ideale. (2016: 310-11)

Posle evakuacije iz Medove i povratka u London, ovi požrtvovani i Srbima naklonjeni Englezi doživljavaju različitu sudbinu. Oporavivši se u Engleskoj, Klod Askju se u maju 1916. godine vraća u Grčku, gde na ostrvu Vidu prisustvuje osvećenju kamenog krsta podignutog u slavu stradalih srpskih vojnika, a potom sa Srbima boravi u Solunu, gde mu se pridružuje i Alis, oktobra iste godine. U proleće 191\%. godine Alis odlazi na Krf, da radi za Crveni krst Srbije. Bračni par Askju nastradao je u oktobru 1917. godine, vraćajući se iz Italije na Krf, kada 
je nemačka podmornica torpedovala njihov brod. Telo Kloda Askjua nikada nije pronađeno, a telo Alis Askju pronašao je lokalni ribar na Korčuli, gde je i sahranjena.

Mejbel Sinkler Stobart je po povratku u Englesku pisala i držala predavanja o svom ratnom iskustvu, a honorare od predavanja poklanjala je Crvenom krstu Srbije. Dosta je putovala po Engleskoj i Americi i ukazivala na potrebu osnivanja pokretnih bolnica na linijama fronta. Nosilac je srpskih odličja - Ordena Belog Orla i Ordena Svetog Save. Po završetku Velikog rata Stobartova počinje da se interesuje za misticizam i spiritualizam i organizuje seanse u svome domu u Dorsetu, a ta interesovanja se naročito produbljuju posle smrti njenog drugog supruga, Džona Grinhalga (John Greenhalgh). Stobartova je umrla u dubokoj starosti, u devedeset drugoj godini, i sahranjena je u mestu Stadlend u Dorsetu.

Svojim praktičnim delovanjem i svojim pisanjem Askjuovi i Stobartova trajno su zadužili srpski narod. Došavši u Srbiju sa željom da je upoznaju i pomognu joj, pokazali su rezervu prema reputaciji koju je imala u engleskom javnom mnjenju, a boravak u Srbiji, upoznavanje sa njenim ljudima i istorijom, uverio ih je da je ta rezerva itekako bila na mestu. Njihovi putopisi nastali iz neposrednog iskustva, najpre tokom zatišja u borbama, a potom i za vreme tragičnog povlačenja srpske vojske, predstavljaju redak i dragocen izazov balkanizmu, proistekao iz otvorenih, širokih umova i nesvakidašnjeg filantropskog dara.

\section{IZVORI I CITIRANA LITERATURA}

AskJu, Alis i Klod. Opustošena zemlja: Srbija kako smo je mi videli. Novi Sad: Platoneum, 2012.

IGNJAČEvić, Svetozar. Zemlja čuda u izlomljenom ogledalu (ponovo): Jugoslovenska tematika u modernoj engleskoj književnosti. Beograd: Filološki fakultet i Narodna knjiga, Beograd, 2000.

MoмčILović, Branko. Britanski putnici o našim krajevima u XIX veku. Novi Sad: Matica srpska, 1993. 
Milica Spremić Končar: Opustošena zemlja: dva engleska svedočanstva...

Stoвart, Mejbel Sinkler. Plameni maču Srbiji i drugde. Novi Sad: Prometej i Radio televizija Srbije, Beograd, 2016.

Todorova, Marija. Imaginarni Balkan. Beograd: Biblioteka XX vek, 1999.

Milica Spremić Končar

\section{THE STRICKEN LAND: TWO ENGLISH TRAVELOGUES ABOUT WORLD WAR I IN SERBIA}

\section{Summary}

Drawing on Maria Todorova's concept of Balkanism, this paper analyses two English travelogues from World War I - The Sticken Land: Serbia As We Saw It by Alice and Claude Askew, and Mrs. St. Clair Stobart's The Flaming Sword in Serbia and Elsewhere - to show how opposed they are to the dominant discourse of the times in which they were written. The Askews and Mrs. Stobart spent the greater part of 1915 in Serbia, witnessing both the period of ceasefire in spring and summer and the Great Retreat of the Serbian Army through Serbia, Montenegro and Albania in autumn and early winter of the same year. Instead of a scornful and deprecating attitude typically dominating the writings on the South Slavonic parts of Europe, they show great respect and admiration for the Serbs and condemn the shameful treason commited by the Allies.

Keywords: World War I, Serbia, Balkanism, travel books.

Univerzitet u Beogradu

Filološki fakultet

m.spremickoncar@gmail.com 